\title{
Embarazo en una adolescente con cirrosis e hipertensión portal: prevención de la hemorragia por várices esofágicas
}

\author{
Alejandro Costaguta, ${ }^{1}$ Walter Araujo, ${ }^{1}$ Sergio Plaza, ${ }^{2}$ Pablo Candarle, ${ }^{1}$ Soledad Albornoz ${ }^{3}$ \\ ${ }^{1}$ Servicio de Gastroenterología, Hepatología y Nutrición, Sanatorio de Niños. Rosario, Argentina. \\ ${ }^{2}$ Servicio de Anestesia, Sanatorio de Niños. Rosario, Argentina. \\ ${ }^{3}$ Servicio de Obstetricia, Maternidad Oroño. Rosario, Argentina.
}

Acta Gastroenterol Latinoam 2020;50(2):191-197

Recibido: 29/01/2019 / Aceptado: 19/03/2019 / Publicado online: 29/06/2020

\section{Resumen}

El embarazo en pacientes con cirrosis e hipertensión portal es un escenario con alto riesgo de complicaciones tanto para la madre como para el feto. Entre ellas, el sangrado por várices esofágicas es una de las más temidas. La disponibilidad de tratamientos efectivos puede reducir este riesgo, por lo que la profilaxis primaria debería ser analizada en estas pacientes. Presentamos el caso de una adolescente embarazada con historia de hipertensión portal secundaria a cirrosis hepática por colangitis esclerosante primaria, en quien se realizó prevención primaria del sangrado por várices esofágicas con tratamiento endoscópico, logrando un embarazo y parto a término, sin complicaciones.

Palabras claves. Hipertensión portal, cirrosis, embarazo, várices esofágicas, colangitis esclerosante primaria, colitis ulcerosa.

Correspondencia: Alejandro Costaguta

Alvear 863. Servicio de Gastroenterología, Hepatología y Nutrición.

Sanatorio de Niños. Rosario, Argentina

Tel.: (0341) 420-4400

Correo electrónico: alejandro.costaguta@gmail.com

\section{Introducción}

El embarazo es un estado fisiológico especial en la vida de una mujer, durante el cual se producen cambios hemodinámicos que en pacientes con historia previa de hipertensión portal (HTP) pueden generar complicaciones severas, como la hemorragia por várices esofágicas (VE). Frente a este escenario no existen guías claras de conducta, y el médico debe tomar decisiones basadas en la escasa experiencia publicada. ${ }^{1,2}$

Reportamos el caso de una adolescente con hipertensión portal por cirrosis hepática secundaria a colangitis esclerosante primaria (CEP), que se presentó con un embarazo en el primer trimestre y en quien se realizó profilaxis primaria para la prevención del sangrado por VE, con resultado exitoso.

\section{Caso clínico}

Se trata de una paciente de 19 años que consultó en su primer trimestre de embarazo. Presentaba diagnóstico de colangitis esclerosante primaria desde los 4 años, asociada a colitis ulcerosa, cistinuria e hipotiroidismo. La paciente concurría periódicamente a los controles clínicos, con una evolución estable de su hepatopatía (cirrosis compensada). Realizaba tratamiento con ácido ursodesoxicólico, sulfasalazina, ácido fólico, citrato de potasio y suplementos vitamínicos. Los exámenes habituales de laboratorio mostraban plaquetopenia y leucopenia esperables por su patología de base, no presentaba anemia, la bilirrubina y los tiempos de coagulación eran normales, las transaminasas se encontraban discretamente elevadas, y había 
un franco aumento de las enzimas de colestasis (Tabla 1). La ecografía abdominal informaba heterogeneidad del lóbulo hepático izquierdo, esplenomegalia $(18 \mathrm{~cm})$ y una litiasis de 5,6 mm a nivel del riñón izquierdo, como datos positivos. La densitometría ósea era acorde a la edad (Score Z: -1). Los controles endoscópicos hasta los dos años previos al embarazo revelaban presencia de várices esofágicas pequeñas sin estigmas. En la endoscopía, realizada al cuarto mes de gestación, se evidenciaron várices con alto riesgo de sangrado, representadas por tres cordones grandes con signos rojos en tercio inferior de esófago, además de gastropatía hipertensiva moderada y várices gástricas en curvatura menor (GOV 1).

Tabla 1. Valores del laboratorio al momento de la primer consulta.

\begin{tabular}{lc}
\hline Hematocrito (\%) & 32 \\
Hemoglobina $(\mathrm{g} / \%)$ & 11 \\
Glóbulos blancos $\left(/ \mathrm{mm}^{3}\right)$ & 2.800 \\
Plaquetas $\left(/ \mathrm{mm}^{3}\right)$ & 56.000 \\
Bilirrubina total (directa) mg\% & $0,6(0,1)$ \\
TGO (AST) UI/L & $89(\mathrm{VN}=32)$ \\
TGP (ALT) UI/L & $103(\mathrm{VN}=31)$ \\
GGT UI/L & $342(\mathrm{VN}=32)$ \\
FA UI/L & $1065(\mathrm{VN}=105)$ \\
RIN & 1,4 \\
\hline
\end{tabular}

RIN: Razón Internacional Normalizada.

VN: valor normal.

La paciente ingresó a un régimen de profilaxis primaria, realizando tres sesiones de ligadura y una final de esclerosis, con reducción significativa del tamaño de las várices y desaparición de los signos rojos hacia el final del tratamiento (Figura 1). La gastropatía se mantuvo estable. No se observaron complicaciones durante todo el período. Los procedimientos fueron realizados bajo cuidados anestésicos específicos, con controles obstétricos y monitoreo del bienestar fetal.

Hacia la semana $38^{\circ}$ de gestación se programó una cesárea, de la que nació un varón vigoroso (Apgar 9/10), con peso adecuado para la edad gestacional $(2870 \mathrm{~g})$, que requirió atención neonatal por un síndrome de taquipnea transitoria, e hiperbilirrubinemia no conjugada, resuelta con luminoterapia en 48 horas, y siendo externado al sexto día. La madre cursó su puerperio sin complicaciones y fue dada de alta al tercer día de internación.
Figura 1. A) Aspecto endoscópico de las várices esofágicas en la primera endoscopía. B) Aspecto endoscópico de las várices esofágicas al final del tratamiento: se observa reducción significativa del número y tamaño, con desaparición de los signos rojos.
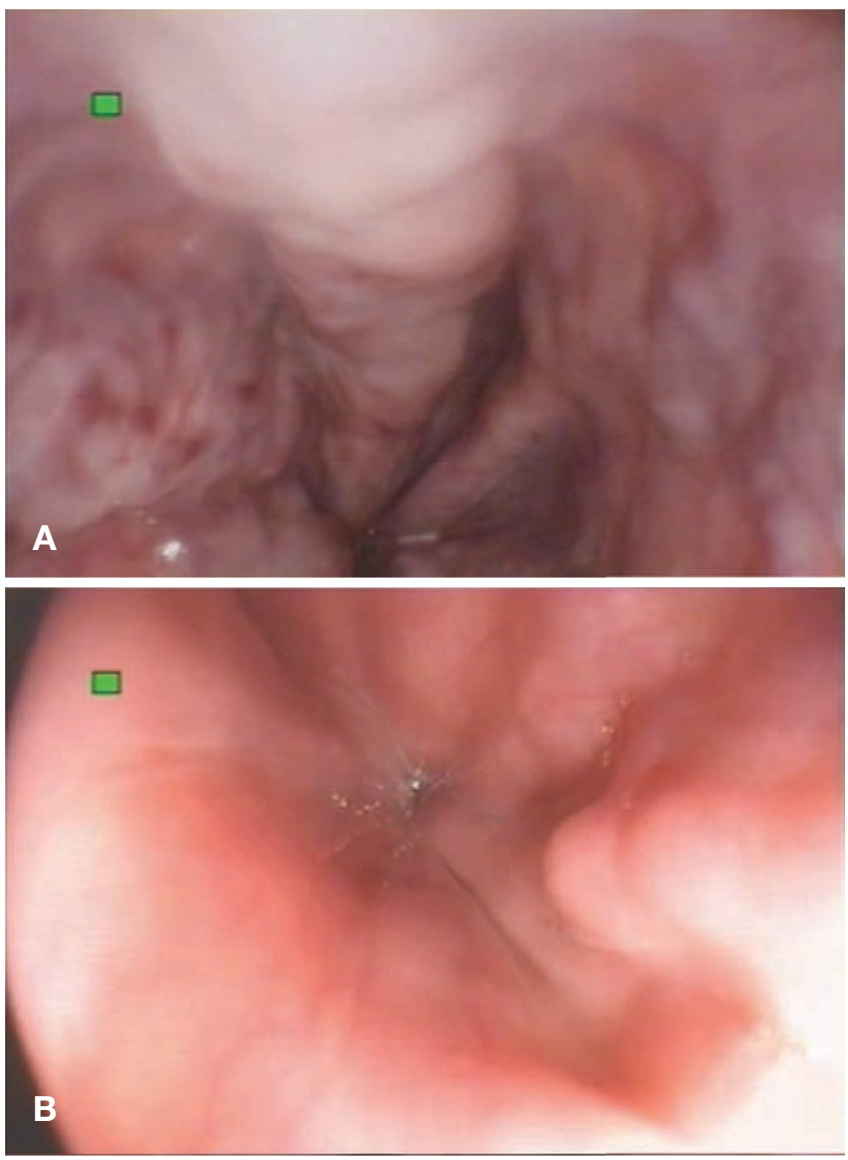

\section{Discusión}

El embarazo es considerado un evento poco frecuente en pacientes cirróticas debido a que los ciclos anovulatorios, las alteraciones del metabolismo endócrino y la edad avanzada con la que se presenta la mayoría de ellas impactan negativamente en la fertilidad. ${ }^{1-3}$ Sin embargo, en los últimos años este concepto está siendo cuestionado como resultado de las mejoras en las técnicas reproductivas disponibles y los avances en los tratamientos de las hepatopatías crónicas, lo que podría determinar que este escenario sea cada vez más frecuente en el futuro inmediato. ${ }^{4}$ Estimaciones actuales han reportado una prevalencia de 45 cirróticas por cada 100.000 mujeres embarazadas. 5

Las dos condiciones, embarazo y cirrosis, interactúan y se modifican mutuamente dando lugar a una serie importante de complicaciones tanto en el feto (aborto espontáneo, prematurez, retardo del crecimiento intrauterino) como en la madre (hemorragia digestiva, insuficiencia hepática, hipertensión arterial, aneurisma de la arteria esplé- 
nica), entre otros. ${ }^{1,6}$ En estudios retrospectivos y series de casos, la tasa de complicaciones alcanza a más de la mitad de las pacientes, con una mortalidad materna que varía entre el $2 \%$ y $10 \% .^{3-5}$

La gestación origina importantes cambios, expresados en un estado circulatorio hiperdinámico con aumento del flujo esplácnico, lo que determina que hasta dos tercios de las mujeres embarazadas saludables experimenten una HTP transitoria. ${ }^{1}$ Estos cambios se producen principalmente a expensas del aumento del volumen plasmático (que puede llegar hasta el 50\%), del volumen minuto cardíaco (que se incrementa alrededor del 40\%) y de la disminución de la resistencia vascular periférica. ${ }^{1}$

El aumento de la presión intraabdominal provocado por el crecimiento del útero gestante es otro factor que contribuye a empeorar la HTP. ${ }^{2}$

Teniendo en cuenta estas consideraciones, en una paciente con HTP preexistente es esperable un incremento en el riesgo de hemorragia por VE, particularmente cuando se asocia a cirrosis (RR 400 veces mayor que en mujeres sin HTP, según algunas estimaciones). ${ }^{7-9}$

La morbimortalidad materno-fetal asociada a la hemorragia por VE puede ser reducida adoptando un método de prevención del primer sangrado (profilaxis primaria). Aunque no hay ensayos controlados que comparen la eficacia de los diferentes procedimientos endoscópicos en la embarazada con HTP, la ligadura con bandas ha demostrado ser un método seguro y efectivo en otros escenarios." 10

El uso de antagonistas beta adrenérgicos no selectivos (propanolol) es otra opción, pero la reducción del flujo esplácnico que provoca puede tener consecuencias indeseables en la circulación uterina, con aumento del riesgo de hipoglucemia, bradicardia y retardo de crecimiento fetal. ${ }^{2}$

$\mathrm{Si}$ bien es cierto que el riesgo de sangrado por VE, aunque probablemente elevado, es esencialmente desconocido, la conducta de esperar para intervenir en el caso de producirse una hemorragia enfrenta a la madre y al feto con una morbimortalidad indeseable y limitaciones en el arsenal terapéutico disponible. La vasopresina, por su efecto estimulante sobre las contracciones uterinas, está contraindicada, y el octreótido (categoría B de la FDA) provoca vasoespasmo esplácnico y su utilización debería evitarse en este contexto. ${ }^{2}$

Otros métodos más agresivos, como los procedimientos endovasculares (TIPS) o las derivaciones quirúrgicas en emergencia, se reservan solo para casos extremos, y se acompañan de una elevada tasa de complicaciones, incluyendo el desarrollo de encefalopatía. ${ }^{4}$

La endoscopía es segura durante el embarazo, pero debe postergarse hasta el segundo trimestre cuando sea posible, tomando consideraciones especiales para el cuidado materno-fetal. Una sedación excesiva puede producir hipotensión e hipoxia, y una posición supina puede hacer que el útero grávido comprima la vena cava inferior conduciendo a una disminución del flujo sanguíneo uterino e hipoxia fetal, por lo que se recomienda el decúbito lateral izquierdo. El uso de benzodiazepinas está desaconsejado (categoría $\mathrm{D}$ de la FDA), siendo preferibles la meperidina y el propofol en su reemplazo. ${ }^{2,11}$ El sevoflurano también sería una opción segura. ${ }^{12}$

Teniendo en cuenta estas consideraciones, tomamos la decisión de indicar profilaxis primaria con ligadura elástica de las várices esofágicas que presentaba nuestra paciente, entendiendo que ofrecía la mejor relación riesgo/beneficio, completando con una sesión de escleroterapia una vez que las várices se habían reducido significativamente en tamaño dado la dificultad técnica que presenta la ligadura de pequeños cordones en el contexto de intervenciones previas.

La elección del tipo de parto en estas pacientes es motivo de controversia. ${ }^{1-3}$ En nuestro caso, la indicación de cesárea estuvo basada en la consideración de que el parto vaginal podía incrementar el riesgo de sangrado por VE frente a los repetidos esfuerzos de pujo (maniobra de Valsalva). La presencia de un cirujano con experiencia en hipertensión portal en el momento del parto fue prevista, aunque no se requirió su intervención.

\section{Conclusión}

El embarazo en pacientes portadoras de hipertensión portal, especialmente en presencia de cirrosis, es un evento de alto riesgo para la madre y el feto, que debe ser controlado en centros con capacidad para resolver las potenciales complicaciones que se puedan presentar.

Existe poca información para ayudar en la toma de decisiones terapéuticas, tanto en lo referido al manejo de las VE como al tipo de parto que debería indicarse, lo que debe adaptarse a las particularidades de cada caso, en el contexto de un equipo multidisciplinario.

En nuestro caso, la profilaxis primaria basada en una combinación de ligadura elástica y esclerosis de las VE, asociado a la realización del parto por cesárea programada resultó en una evolución favorable y sin complicaciones para la madre y el niño.

\section{Conflicto de intereses. Ninguno que declarar.}

Agradecimientos. Los autores agradecen a la Dra. Silvina Balbarrey y al Dr. Luis Sabbatini por su activa participación en el cuidado de la paciente. 


\section{Referencias}

1. Sandhu BS, Sanyal AJ. Pregnancy and Portal Hypertension. In Arun J. Sanyal, Vijay H Shah. Portal Hypertension. Pathobiology, Evaluation, and Treatment. Totowa, New Jersey: Humana Pess 2005: 365-381.

2. Tran TT, Ahn J, Reau NS. ACG Clinical Guideline: Liver Disease and Pregnancy. Am J Gastroenterol 2016; 111: 176-194.

3. Sobral M, Granja C, Sampaio M, Guerreiro F. Bleeding from esophageal varices in pregnancy. BMJ Case Rep 2013. pii: bcr2013009653. doi: 10.1136/ bcr-2013-009653

4. Degli Esposti S. Pregnancy in Patients with Advanced Chronic Liver Disease. Clin Liv Dis 2014; 4: 62-68. doi: 10.1002/cld.415

5. Tan J, Surti B, Saab S. Pregnancy and Cirrhosis. Liver Transpl 2008; 14: 1081-1091.

6. Ryan JM, Heneghan MA. Pregnancy and the Liver. Clin Liv Dis 2014; 4: 51-54. doi: 10.1002/cld.361

7. Britton RC. Pregnancy and esophageal varices. Am J Surg 1982; 43: 421-425.
8. Costaguta A, Álvarez F. Hipertensión portal en pediatría. I: Aspectos fisiopatológicos y clínicos. Arch Argent Pediatr 2010; 108: 239-242.

9. Costaguta A, Álvarez F. Hipertensión portal en pediatría. II: Complicaciones hemorrágicas. Arch Argent Pediatr 2010; 108: 337-342.

10. Duché M, Ducot B, Ackermann O, Guérin F, Jacquemin E, Bernard $\mathrm{O}$. Portal hypertension in children: High-risk varices, primary prophylaxis and consequences of bleeding. J Hepatol 2017; 66: 320-327.

11. Onyi Onuoha. Does Anesthesia Increase the Risk to the Parturient Undergoing Nonobstetric Surgery? In Lee A. Fleisher. Evidence-Based Pactice of Anesthesiology. Philadelphia, Pennsylvania: Elsevier 2013: 516-521.

12. Tang L, Liu H, Wu Y, Li M, Li W, Jiang M, Hou J, Jiang Y, Xia Z, Meng Q. Sevoflurane may be more beneficial than propofol in patients receiving endoscopic variceal ligation and endoscopic variceal sclerotherapy: A randomized, double-blind study. Exp Ther Med 2017; 14: 3145-3152. 


\title{
Pregnancy in an adolescent girl with cirrhosis and portal hypertension: prevention of bleeding from esophageal varices
}

\author{
Alejandro Costaguta, ${ }^{1}$ Walter Araujo, ${ }^{1}$ Sergio Plaza, ${ }^{2}$ Pablo Candarle, ${ }^{1}$ Soledad Albornoz ${ }^{3}$ \\ ${ }^{1}$ Servicio de Gastroenterología, Hepatología y Nutrición, Sanatorio de Niños. Rosario, Argentina. \\ ${ }^{2}$ Servicio de Anestesia, Sanatorio de Niños. Rosario, Argentina. \\ ${ }^{3}$ Servicio de Obstetricia, Maternidad Oroño. Rosario, Argentina.
}

Acta Gastroenterol Latinoam 2020;50(2):230-236

Recibido: 29/01/2019 / Aceptado: 19/03/2019 / Publicado online: 29/06/2020

\begin{abstract}
Summary
Pregnancy in patients with cirrhosis and portal hypertension is a high-risk scenario, both for the mother and the fetus. Among all possible complications, bleeding from esophageal varices is one of the most feared. Availability of current therapies can reduce that risk effectively, making primary prophylaxis an appealing option that should be considered. We describe the case of a pregnant adolescent with a previous history of portal hypertension due to hepatic cirrhosis in which endoscopic primary prophylaxis of bleeding esophageal varices was carried out, achieving a term pregnancy without complications.
\end{abstract}

Key words. Portal hypertension, cirrhosis, pregnancy, esophageal varices, primary sclerosing cholangitis, ulcerative colitis.

Correspondencia: Alejandro Costaguta

Alvear 863. Servicio de Gastroenterología, Hepatología y Nutrición. Sanatorio de Niños. Rosario, Argentina

Tel.: (0341) 420-4400

Correo electrónico: alejandro.costaguta@gmail.com

\section{Introduction}

Pregnancy is a special period in woman's life, during which important hemodynamic changes take place, placing patients with previous history of portal hypertension $(\mathrm{PH})$ at risk of severe complications, like hemorrhage from esophageal varices (EV). In these cases, there is no uniform consensus on the best management, and the medical team has to address the problem without clear guidelines, based on the scarce information published. ${ }^{1,2}$

We report the case of an adolescent with $\mathrm{PH}$ due to liver cirrhosis presenting at three months of gestation in which successful endoscopic primary prophylaxis of bleeding from EV was carried out, giving rise to a term pregnancy with no complications.

\section{Case report}

A 19 years old patient came to consult during the third month of pregnancy. She had been diagnosed with sclerosing cholangitis associated with ulcerative colitis since the age of 4 in addition to cystinuria and hypothyroidism, for which she attended to scheduled appointments, in the setting of a compensated cirrhosis. She was on treatment with ursodeoxycholic acid, sulfasalazine, folic acid, potassium citrate, and vitamin supplements. As expected, her blood tests showed low values for leucocytes and platelets, whit elevated liver enzymes, but normal values for the rest 
of determinations (Table 1). Liver ultrasound revealed a heterogeneous liver, splenomegaly, and a 5.6 $\mathrm{mm}$ lithiasis in the left kidney. Bone densitometry was within normal range ( $Z$ score: -1$)$. Previous endoscopic controls up to 2 years before her pregnancy revealed small EV without risks stigmata. An upper endoscopy performed at 4 months of gestation revealed high-risk varices represented by 3 big vessels with red spots, in the distal esophagus. Mode-

Table 1. Biochemical profile at first visit.

\begin{tabular}{lc}
\hline Hematocrit (\%) & 32 \\
Hemoglobin $(\mathrm{g} / \%)$ & 11 \\
Leucocytes $\left(/ \mathrm{mm}^{3}\right)$ & 2,800 \\
Platelets $\left(/ \mathrm{mm}^{3}\right)$ & 56,000 \\
Total bilirubin (direct) $(\mathrm{mg} \%)$ & $0.6(0.1)$ \\
AST (IU/L) & $89(\mathrm{NV}=32)$ \\
ALT (IU/L) & $103(\mathrm{NV}=31)$ \\
GGT (IU/L) & $342(\mathrm{NV}=32)$ \\
Alkaline phosphatase (IU/L) & $1065(\mathrm{NV}=105)$ \\
INR & 1.4 \\
\hline
\end{tabular}

INR: Internacional Normalized Ratio.

NV: normal value.

rate portal hypertensive gastropathy and gastric varices in the lesser curve (GOV1) was also recorded. The patient was started on a primary prophylaxis regime, with 3 sessions of endoscopic variceal ligation and a last one with $1 \%$ polidocanol injection, achieving a significant reduction of variceal size and disappearing of red signs at the end of follow up (Figure 1). Procedures were done under specific anesthetic and obstetric control, with monitoring of fetal condition. No complications were observed.

At $38^{\text {th }}$ week of gestation, a cesarean section was programmed giving birth to a healthy male newborn (Apgar 9/10) weighing 2,870 g which developed a transient tachypnea and unconjugated hyperbilirubinemia without any remarkable consequences, being discharged on the 6th postpartum day. The mother was also in excellent condition and discharged at day 3 of hospitalization.
Figure 1. A) Endoscopic aspect of esophageal varices at first session. B) Endoscopic aspect at the end of treatment: small residual varices without red signs.
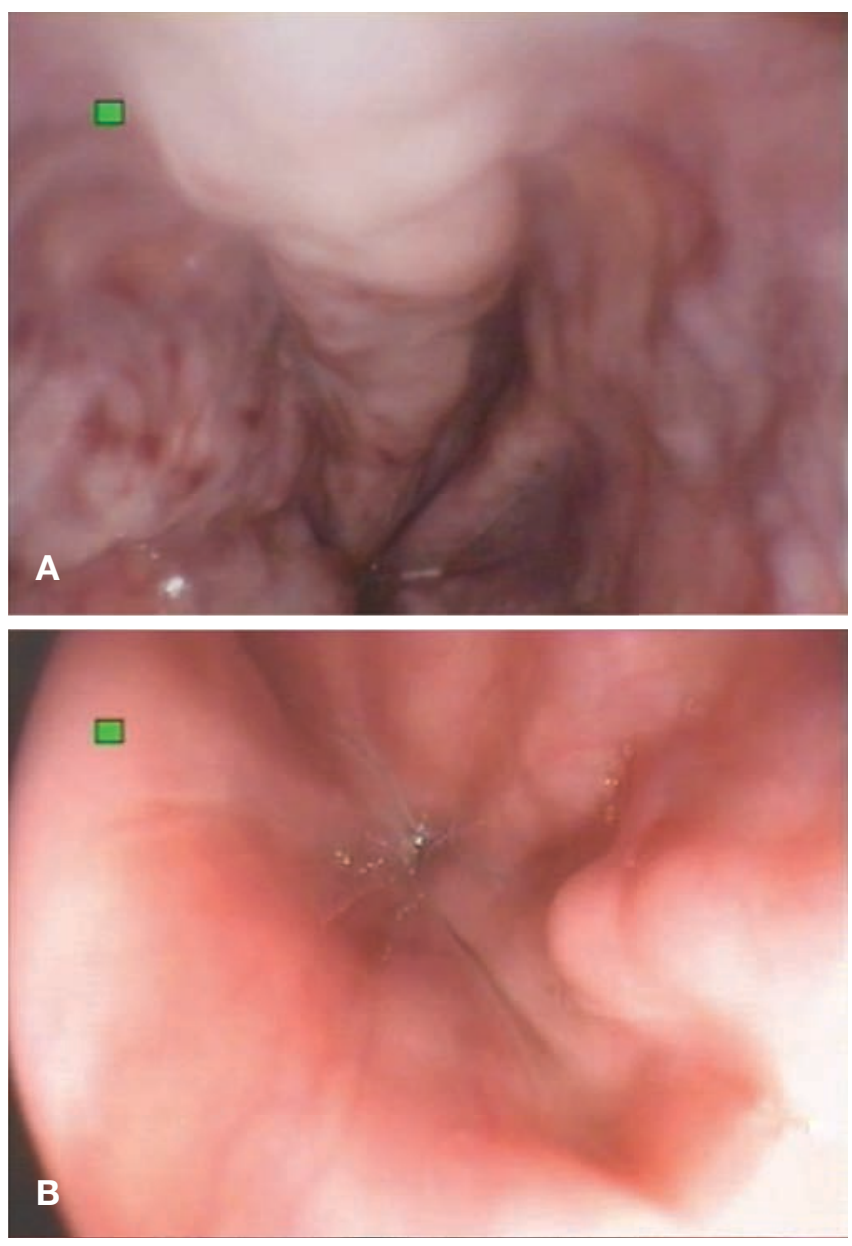

\section{Discussion}

Pregnancy is considered an unusual event in cirrhotic women owing to the abnormalities of menstrual cycles, endocrine metabolism, and advanced age of most of them, with its negative impact on fertility. ${ }^{1-3}$ However, this concept has been challenged in the last years as a result of the progress attained in the treatment of infertility and chronic liver diseases. This could make foresee a new scenario, with increasing frequency of pregnancy in cirrhotic women in the near future. ${ }^{4}$ Current estimations have set this prevalence in 45 cirrhotic over 100,000 pregnancies. ${ }^{5}$

The two conditions, pregnancy and cirrhosis, interact and modify each other, potentially giving rise to severe complications either in the fetus (spontaneous abortion, prematurity, intrauterine growth retardation) or the mother (gastrointestinal bleeding, hepatic insufficiency, arterial hypertension, splenic artery aneurysm), among others.1, 6 Retrospective studies and case series 
showed that almost half of these pregnancies suffered complications, with a maternal mortality rate between 2 to $10 \% .^{3-5}$

Gestation produces important changes expressed through a hyper dynamic circulatory state with increase in the splanchnic flow, determining that up to $2 / 3$ of healthy pregnant women have a "transient $P H$ ". ${ }^{1}$ Those changes are the consequence of an increase in the plasmatic volume (which can rise 50\%), the cardiac output (up to $40 \%)$ and a fall in the peripheral vascular resistance. ${ }^{1}$ Increased intra-abdominal pressure as a consequence of the uterine growth is another factor worsening $\mathrm{PH} .{ }^{1} \mathrm{Al}-$ together, in a woman with preexistent $\mathrm{PH}$ an increase in the risk of hemorrhage from EV is expected, particularly when cirrhosis is associated (RR 400 times higher according to some estimations). ${ }^{7-9}$

EV-associated hemorrhagic morbidity (and mortality) could be reduced adopting a strategy of prevention of first bleeding (primary prophylaxis). Even in the absence of controlled trials assessing the efficacy of different therapeutic methods in pregnant women with $\mathrm{PH}$, endoscopic variceal ligation has proven to be safe and effective in other scenarios. ${ }^{9,10}$

Use of non-selective beta-blockers (propranolol) could be an option, but the associated reduction of splanchnic flow that ensues could be detrimental to the uterine circulation, with risk of hypoglycemia, bradycardia, and intrauterine growth retardation for the fetus. ${ }^{2}$

Although it is true that the risk of bleeding from EV, even when probably high, is mainly unknown, to intervene when bleeding occurs might confront the mother and fetus with undesirable consequences, and limitations in the therapeutic armamentarium. In fact, vasopressin should be avoided owing to its stimulating effect on the uterine muscle, and octreotide (FDA class B) produces an intense splanchnic vasoconstriction potentially harmful to fetal circulation. ${ }^{2}$

Other, more aggressive methods, like endovascular procedures (TIPS) or emergency surgical shunts, are reserved for extreme conditions and are associated with a high rate of potential complications, including encephalopathy. ${ }^{4}$

Endoscopic procedures are safe during pregnancy, provided they are postponed to the second trimester, and special measures for maternal and fetal safety are adopted. Excessive sedation could produce hypotension and hypoxia, and a supine position of the mother could make the gravid uterus compressing the inferior vena cava with reduction of uterine blood flow and fetal suffering. For this reason, left lateral decubitus of the mother has been recommended during the endoscopy. The use of benzodiazepines (FDA class D) is not recommended. Meperidine or propofol are the sedative drugs preferred. ${ }^{2,11} \mathrm{Se}$ voflurane would also be a safe option. ${ }^{12}$

Keeping in mind all the above considerations, we decided to initiate primary prophylaxis of variceal bleeding with endoscopic band ligation, in view of its best risk/ benefit ratio in our patient. One session of sclerotherapy was performed at the end, when the small size of varices remnant made ligation technically impossible.

Choosing the mode of delivery is another controversial issue. ${ }^{1-3}$ In our case, we decided to perform a cesarean section considering the risk of collateral bleeding during vaginal delivery because of the Valsalva maneuver. The availability of an experienced surgeon with expertise in $\mathrm{PH}$ is desirable during the labor. This was accomplished in our case.

\section{Conclusion}

Pregnancy in patients suffering from $\mathrm{PH}$, especially in the context of cirrhosis is a high-risk event for the mother and the fetus and should be controlled in experienced centers with resources to address the complications that could arise.

There is scarce information to help the physician in addressing the many faces of this complex situation, either in the management of $\mathrm{PH}$ or the type of delivery. This should be tailored to each specific case and managed in the context of a multidisciplinary team.

In our case, endoscopic-based primary prophylaxis of variceal bleeding, together with a programmed cesarean delivery resulted in a favorable outcome, without complications for the mother and the offspring.

Conflict of interest. None to declare.

Acknowledgements. The authors wish to thank Dr. Silvina Balbarrey and Dr. Luis Sabbatini for actively participating in the care of the patient.

\section{References}

- On page 194. 